\title{
Isolation, Identification, and Characterization of a Cellulolytic Bacillus amyloliquefaciens Strain SS35 from Rhinoceros Dung
}

\author{
Shuchi Singh, ${ }^{1}$ Vijayanand S. Moholkar, ${ }^{1,2}$ and Arun Goyal ${ }^{1,3}$ \\ ${ }^{1}$ Center for Energy, Indian Institute of Technology Guwahati, Guwahati, Assam 781 039, India \\ ${ }^{2}$ Department of Chemical Engineering, Indian Institute of Technology Guwahati, Guwahati, Assam 781 039, India \\ ${ }^{3}$ Department of Biotechnology, Indian Institute of Technology Guwahati, Guwahati, Assam 781 039, India
}

Correspondence should be addressed to Vijayanand S. Moholkar; vmoholkar@iitg.ernet.in and Arun Goyal; arungoyl@iitg.ernet.in

Received 30 March 2013; Accepted 8 May 2013

Academic Editors: L. Brusetti, J. Kreth, M. C. Lai, and J. Maupin-Furlow

Copyright @ 2013 Shuchi Singh et al. This is an open access article distributed under the Creative Commons Attribution License, which permits unrestricted use, distribution, and reproduction in any medium, provided the original work is properly cited.

\begin{abstract}
Cellulose hydrolyzing bacteria were isolated from rhinoceros dung and tested for clear zone formation around the colonies on the agar plates containing the medium amended with carboxymethylcellulose as a sole carbon source. Isolates were further screened on the basis of carboxymethylcellulase production in liquid medium. Out of 36 isolates, isolate no. 35 exhibited maximum enzyme activity of $0.079 \mathrm{U} / \mathrm{mL}$ and was selected for further identification by using conventional biochemical tests and phylogenetic analyses. This was a Gram-positive, spore forming bacterium with rod-shaped cells. The isolate was identified as Bacillus amyloliquefaciens SS35 based on nucleotide homology and phylogenetic analysis using 16S rDNA and gyrase A gene sequences.
\end{abstract}

\section{Introduction}

Cellulose, a structural carbohydrate of the plant cell wall, is an abundant and ubiquitous polymer. The use of cellulose for the second generation biofuel production involves the hydrolysis of cellulosic biomass, that is, saccharification, to form simple sugar monomers for the fermentation into bioethanol [1-3]. Cellulases are the group of enzymes involved in the conversion of cellulosic substrates to fermentable sugars. Main members of this group include endoglucanase (EC 3.2.1.4), exoglucanase or cellobiohydrolase (EC 3.2.1.91), and $\beta$ glucosidase (EC 3.2.1.21) [4]. The endoglucanase hydrolyzes $\beta-1,4$ bonds in cellulose molecule, whereas exoglucanase cleaves the ends to release cellobiose, and $\beta$-glucosidase converts cellobiose to glucose [5]. Several cellulase producing fungi such as Aspergillus, Rhizopus, and Trichoderma species [6,7] and bacteria such as Bacillus, Clostridium, Cellulomonas, Thermomonospora, Ruminococcus, Bacteroides, Erwinia, and Acetivibrio species [8-10] have been identified. However, the isolation and characterization of novel cellulose hydrolyzing enzymes from bacteria are still a highly active research area, because bacteria have a higher growth rate than fungi, leading to greater production of enzymes [11]. Also, the habitat of bacteria covers different environmental niches, which favors the existence of versatile strains such as thermophiles [12], psychrophiles, alkaliphiles, and acidophiles. The culturable cellulase producing bacteria have been isolated from the variety of sources such as composting heaps, decaying agricultural wastes, the feces of cow [13] and elephant, gastrointestinal tract of buffalo and horse [14], soil, and extreme environments like hot-springs [15]. Cellulose degrading bacteria play an important role in energy supply for forage animals. Wahyudi et al. [14] and Varga and Kovler [16] have reported that the feed fibers were not completely converted to animal product in intensive animal farming, and $20-70 \%$ undigested cellulose was carried out with feces. Some studies have explained that the crude fiber degradation in gut is not optimal, and the fiber content of feces is still high [17], which can be utilized efficiently by microbes present in the feces of the herbivores. Rhinoceros are presumed to have an efficient system for cellulose digestion, as its main food wild grass primarily consists of cellulose. In this study, the dung of the pachyderm from Kaziranga National Park, Assam, India, has been used as the source of cellulolytic bacteria. 


\section{Materials and Methods}

2.1. Substrate and Chemicals. Carboxymethylcellulose (CMC) (low viscosity, 50-200 cP) was procured from Sigma Aldrich (St. Louis, Mo, USA). Medium components and congo red (analytical grade) were procured from Hi-Media Pvt. Ltd., India.

2.2. Sample Collection. The dung sample of one-horned Indian Rhinoceros (Rhinoceros unicornis) was collected from its natural habitat, Kaziranga National Park, Assam, India. Presterilized spatula and plastic bags were used for sample collection, and before bacterial isolation the samples were stored at $4^{\circ} \mathrm{C}$ in ice box for approximately $12 \mathrm{~h}$.

2.3. Isolation of Cellulolytic Bacteria. Dung sample $(0.5 \mathrm{~g})$ was suspended with $50 \mathrm{~mL} 0.85 \%(\mathrm{w} / \mathrm{v})$ sterile $\mathrm{NaCl}$ solution in a $250 \mathrm{~mL}$ conical flask, which was shaken at $180 \mathrm{rpm}$ for $1 \mathrm{~h}$ at $37^{\circ} \mathrm{C}$. Serial dilutions from $10^{0}$ to $10^{-7}$ were prepared using sterilized saline solution. An aliquot of $100 \mu \mathrm{L}$ of each dilution was spread plated onto Bushnell Haas medium (BHM) [18] agar plates amended with carboxymethylcellulose (CMC) ( $\mathrm{pH} 7.0)$ containing (g/L) CMC (10.0), $\mathrm{K}_{2} \mathrm{HPO}_{4}$ (1.0), $\mathrm{KH}_{2} \mathrm{PO}_{4}$ (1.0), $\mathrm{MgSO}_{4} \cdot 7 \mathrm{H}_{2} \mathrm{O}(0.2), \mathrm{NH}_{4} \mathrm{NO}_{3}$ (1.0), $\mathrm{FeCl}_{3} \cdot 6 \mathrm{H}_{2} \mathrm{O}(0.05), \mathrm{CaCl}_{2}(0.02)$, and agar $(20.0)[19,20]$. The plates were incubated at $37^{\circ} \mathrm{C}$ for $96 \mathrm{~h}$.

2.4. Qualitative Screening of Cellulolytic Bacteria by Plate Staining Method. Morphologically dissimilar and discrete colonies were picked from different dilution plates and streaked on separate BHM-CMC plate with grids drawn over it and incubated at $37^{\circ} \mathrm{C}$ for $96 \mathrm{~h}$. The replica plates were also prepared separately for staining [21]. The replica plates were flooded with $0.3 \%$ congo red for $20 \mathrm{~min}$. The stain was poured off, and the plates were washed with $1 \mathrm{M} \mathrm{NaCl}$ [22]. The isolates showing clear zone around the colonies were picked from master plate and further used for the enzyme production in liquid medium. The selected cultures were maintained on nutrient agar slants containing $(\mathrm{g} / \mathrm{L})$ peptone (5.0), beef extract (1.0), yeast extract (2.0), $\mathrm{NaCl}$ (5.0), and agar (20.0). The culture slants were stored at $4^{\circ} \mathrm{C}$ and subcultured every $10-15$ days.

2.5. Quantitative Determination of Extracellular Carboxymethylcellulase (CMCase) Production. The isolates, selected on the basis of plate staining method, were grown in $50 \mathrm{~mL}$ enzyme production medium (at $\mathrm{pH}$ 7.0) containing the following components $(\mathrm{g} / \mathrm{L})$ : CMC (10.0), $\mathrm{K}_{2} \mathrm{HPO}_{4}$ (1.0), $\mathrm{KH}_{2} \mathrm{PO}_{4}(1.0), \mathrm{MgSO}_{4} \cdot 7 \mathrm{H}_{2} \mathrm{O}(0.2), \mathrm{NH}_{4} \mathrm{NO}_{3}$ (1.0), $\mathrm{FeCl}_{3} \cdot 6 \mathrm{H}_{2} \mathrm{O}$ (0.05), $\mathrm{CaCl}_{2}(0.02)$, and yeast extract (5.0). This medium is the same as the previously used medium during isolation, with the only difference of addition of yeast extract. This addition is to provide additional nitrogen source and enhance the growth rate. $50 \mathrm{~mL}$ medium (containing $2 \%$ inoculum) was taken in $250 \mathrm{~mL}$ Erlenmeyer flask and incubated at $37^{\circ} \mathrm{C}$ at $180 \mathrm{rpm}$ for $72 \mathrm{~h}$. After every $6 \mathrm{~h}$, the culture was centrifuged at $12000 \mathrm{~g}$ for $20 \mathrm{~min}$ at $4^{\circ} \mathrm{C}$. The cellfree culture broth containing the crude enzyme was used for estimation of CMCase activity. Based on the higher CMCase activity (as described later), an isolate SS35 (named after its colony number) was selected for further characterization and identification. The enzyme production by the isolate SS35 was monitored with cell growth at $600 \mathrm{~nm}$ using UV-visible spectrophotometer (Perkin Elmer, Model lambda-45).

2.6. CMCase Activity Assay. The CMCase activity (U/mL) was measured by estimation of reducing sugars liberated from CMC. The enzyme assay was carried out by incubating the enzyme with $\mathrm{CMC}$ for $15 \mathrm{~min}$ at $37^{\circ} \mathrm{C}$. The reaction mixture $(100 \mu \mathrm{L})$ contained $50 \mu \mathrm{L}$ of enzyme and $1.0 \%(\mathrm{w} / \mathrm{v})$ final concentration of CMC in $50 \mathrm{mM}$ phosphate buffer $(\mathrm{pH}$ 7.0). The reducing sugar was estimated by the method of Nelson and Somogyi [23, 24]. The absorbance was measured at $500 \mathrm{~nm}$ using a UV-visible spectrophotometer (Perkin Elmer, Model lambda-45) against a blank with D-glucose as standard. One unit $(\mathrm{U})$ of cellulase activity is defined as the amount of enzyme that liberates $1 \mu \mathrm{mol}$ of reducing sugar (glucose) in $1 \mathrm{~min}$ at $37^{\circ} \mathrm{C}$ and $\mathrm{pH}$ 7.0.

2.7. Morphological and Biochemical Characterizations of the Isolate SS35. Morphological and biochemical properties of the isolate were identified, evaluated, and compared, as described in Bergey's Manual of Systematic Bacteriology [25]. The cell morphology of the selected isolate was observed under scanning electron microscope (Leo $1430 \mathrm{VP}$, Leo Electron Microscopy Ltd., Cambridge, UK) at $14 \mathrm{kV}$. Gram staining, endospore staining, and urease test were done as per standard protocol [26]. The catalase activity was determined adding few drops of $3 \%(\mathrm{v} / \mathrm{v}) \mathrm{H}_{2} \mathrm{O}_{2}$ to $5 \mathrm{~mL}$ of $18 \mathrm{~h}$ grown culture [27]. The Nitrate Agar slants (M072, HiMedia) were used to test nitrate reducing property of the isolate SS35. BHM amended with starch was used for amylase activity determination. Triple Sugar Iron (TSI) slants (M021I, HiMedia) containing three sugars, namely, glucose, lactose, and sucrose, were used for acid and $\mathrm{H}_{2} \mathrm{~S}$ production test. Acid production after carbohydrate fermentation was detected by the visible change in color from red to yellow. The temperature tolerance test was performed by growing the isolate in nutrient broth and incubating at the temperatures ranging $20^{\circ}-50^{\circ} \mathrm{C}$.

2.8. Analyses of 165 Ribosomal DNA (rDNA) and Partial Gyrase A (gyrA) Gene Sequences. 16S rDNA and partial gyrase A gene sequencing of bacterial culture were done in Xcelris Labs Limited, Ahmedabad, India. The genomic DNA of the isolate SS35 was extracted using Qiagen DNA extraction kit and purified by QIAamp DNA Purification Kit (Qiagen) for nucleotide sequence analysis. The universal 16S rDNA primer 8F (5' AGAGTTTGATCCTGGCTCAG $\left.3^{\prime}\right)$ and 1492R ( $5^{\prime}$ ACGGCTACCTTGTTACGACTT $3^{\prime}$ ) were used for amplification of genomic DNA by polymerase chain reaction (PCR). The gyrA region was amplified using the primers, p-gyrA-F ( $5^{\prime}$ CAGTCAGGAAATGCGTACGTCCTT $3^{\prime}$ ) and p-gyrA-R (5' CAAGGTAATGCTCCAGGCATTGCT $3^{\prime}$ ) [28]. The concentration of each primer in $25 \mu \mathrm{L}$ PCR reaction mixture was $10 \mathrm{pmol}$ and $1 \mathrm{X}$ PCR master mix (MBI Fermentas). The PCR reaction was 
run for 30 cycles in a Thermal Cycler (Eppendorf), and the thermal profile used for the PCR was as follows: initial denaturation at $95^{\circ} \mathrm{C}$ for $2 \mathrm{~min}$, final denaturation at $94^{\circ} \mathrm{C}$ for $30 \mathrm{~s}$, primer annealing at $52^{\circ} \mathrm{C}$ for $30 \mathrm{~s}$, and extension at $72^{\circ} \mathrm{C}$ for $90 \mathrm{~s}$. Full extension of the products was ensured by running a final cycle that included extension for $10 \mathrm{~min}$ at $72^{\circ} \mathrm{C}$. PCR product of $5 \mu \mathrm{L}$ from each tube was mixed with $1 \mu \mathrm{L}$ of $6 \mathrm{X}$ gel loading dye, and this mixture was subjected to electrophoresis on $1.2 \%$ agarose gel to confirm the targeted PCR amplification. The amplified product was excised from the gel and purified using QIAamp DNA Purification Kit (Qiagen). The concentration of the purified DNA was determined, and it was subjected to automated DNA sequencing on ABI 3730xl Genetic Analyzer (Applied Biosystems, USA). The cycle sequencing was carried out using BigDye Terminator v3.1 Cycle sequencing kit following manufacturer's instructions. The cycle sequencing was carried out in a final reaction volume of $20 \mu \mathrm{L}$ using $200 \mu \mathrm{L}$ capacity PCR tube. The cycling protocol was designed for 25 cycles as follows: denaturation at $96^{\circ} \mathrm{C}$ for $10 \mathrm{~s}$, annealing at $52^{\circ} \mathrm{C}$ for $5 \mathrm{~s}$, and extension at $60^{\circ} \mathrm{C}$ for $4 \mathrm{~min}$. After cycling, the extension products were purified and mixed well in $10 \mu \mathrm{L}$ of Hi-Di formamide. Eluted products were placed in a sample plate, heated at $95^{\circ} \mathrm{C}$ for $5 \mathrm{~min}$, chilled, and loaded into autosampler of the instrument. Both the ends of the sequences were verified with the chromatogram file, and the resulted consensus sequences were used to carry out Basic Local Alignment Search Tool (BLAST) with nr database of NCBI GenBank using MEGABLAST algorithm. Multiple sequence alignment was performed by using CLUSTAL W [29], and evolutionary history was inferred using the neighbor-joining method [30]. The evolutionary distances were computed using the Kimura 2-parameters method [31], and phylogenetic analysis was carried out with MEGA4 [32].

\section{Results and Discussion}

3.1. Isolation and Screening of Cellulolytic Bacteria by Plate Staining Method. Among 36 isolates, 9 cellulose hydrolyzing microorganisms were screened on the basis of plate staining method. The isolates (no. 21, 24, 25, 28, 31, 32, 34, 35, and 36) showed clear zone around colonies after staining the plates with congo red and destaining with $1 \mathrm{M} \mathrm{NaCl}$ as shown in Figure 1. However, plate-screening method is not quantitative because of poor correlation between enzyme activity and colony to clear zone ratio [12]. The colonies showing yellowcolored halo zones were picked from replica plate and further screened on the basis of CMCase production in liquid medium. Out of 9 isolates, isolate no. 35 exhibited maximum CMCase activity of $0.079 \mathrm{U} / \mathrm{mL}$ (details given in Table 1). This value was higher than activity of CMCase produced from some known natural isolates (expressed per $\mathrm{mL}$ of cell-free culture broth), for example, Cellulomonas sp. $(0.0336 \mathrm{U} / \mathrm{mL}$, isolated from coir retting effluents), Micrococcus sp. (0.0152 U/mL, isolated from coir retting effluents), Bacillus sp. (0.0197 U/mL, isolated from coir retting effluents), Brevibacillus sp. JXL $(0.02 \mathrm{U} / \mathrm{mL}$, isolated from swine waste), Brevibacillus sp. DUSELG12 $(0.02 \mathrm{U} / \mathrm{mL}$, isolated from gold
TABLE 1: CMCase activity (U/mL cell-free culture broth) of cellulase producing isolates (after $48 \mathrm{~h}$ at $37^{\circ} \mathrm{C}, 180 \mathrm{rpm}$, and medium $\mathrm{pH} 7.0$ ).

\begin{tabular}{lc}
\hline Isolate no. & CMCase activity $(\mathrm{U} / \mathrm{mL})$ \\
\hline 21 & $0.063 \pm 0.008$ \\
24 & $0.059 \pm 0.003$ \\
25 & $0.072 \pm 0.010$ \\
28 & $0.073 \pm 0.008$ \\
31 & $0.071 \pm 0.006$ \\
32 & $0.067 \pm 0.007$ \\
34 & $0.057 \pm 0.004$ \\
35 & $0.079 \pm 0.011$ \\
36 & $0.049 \pm 0.003$ \\
\hline
\end{tabular}

${ }^{*}$ Values are mean $\pm \mathrm{SE}(n=3)$.

mine), Geobacillus sp. DUSELR7 (0.058 U/mL, isolated from gold mine), Geobacillus sp. (0.0113 U/mL, isolated from sugar refinery wastewater), and Bacillus subtilis AS3 $(0.07 \mathrm{U} / \mathrm{mL}$, isolated from cow dung) [33-37]. Ariffin et al. [38] have reported maximum CMCase activity of $0.079 \mathrm{U} / \mathrm{mL}$ by Bacillus pumilus $\mathrm{EB} 3$ produced in a $2 \mathrm{~L}$ stirred tank reactor, which was equal to the CMCase activity of the isolate in this study. Thus, the isolate no. 35 was revealed to be an efficient CMCase producer species and was designated as SS35. Further analysis of this species was done as described below. The growth curve of SS35 along with CMCase production profile (Figure 2) revealed that the enzyme production was associated with cell growth and reached maximum at late log phase. Slight reduction in enzyme production after $48 \mathrm{~h}$ could be a consequence of instability of the enzyme at $37^{\circ} \mathrm{C}$ or the activity of proteases present in the crude enzyme solution.

3.2. Morphological and Biochemical Characterization of the Isolate SS35. The isolate SS35 was found to be rod-shaped cells with a width and length of $0.5-0.6 \mu \mathrm{m}$ and $1.5-1.6 \mu \mathrm{m}$, respectively, as observed under scanning electron microscope (Figure 3). The isolate was found to be a Gram-positive, spore forming bacterium, and it gave positive test for catalase, nitrate reduction, and starch hydrolysis, whereas negative for urease and hydrogen sulfide production. The absence of black precipitate at the base of the tube indicated that hydrogen sulfide was not produced. The color of TSI agar slant was turned from red to yellow, which indicated that the bacterium was able to ferment the sugars glucose, lactose, and sucrose. The temperature tolerance test revealed that the isolate was able to grow at a wide temperature range $20^{\circ}-50^{\circ} \mathrm{C}$. These characteristics have been summarized in Table 2 .

3.3. Identification on the Basis of Phylogenetic Analyses. The phylogenetic tree generated using $16 \mathrm{~S}$ rDNA gene sequences of the isolate SS35 showed that the bacterium has the highest homology with Bacillus amyloliquefaciens NBRC 3035 (GenBank accession no.: AB679994.1) (Figure 4). The bacterial identification using $16 \mathrm{~S}$ rDNA gene sequence is a widely practiced technique, although with limitations for the members of closely related taxa [39]. To overcome this limitation, several studies have been done, which concluded that some 


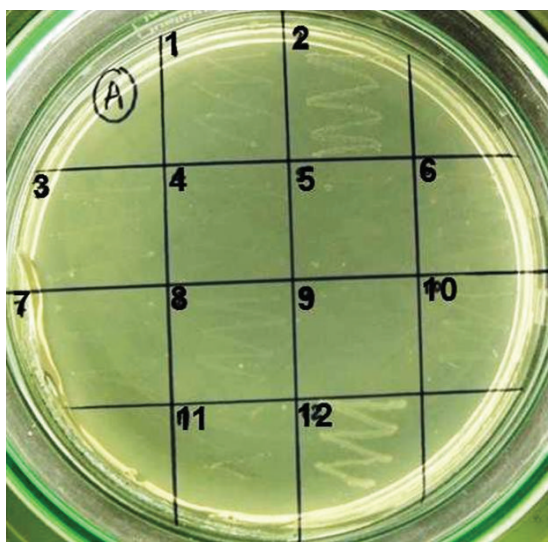

(a1)

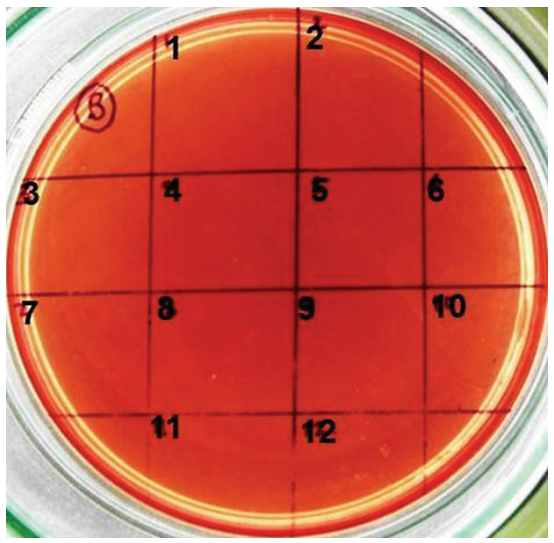

(a2)

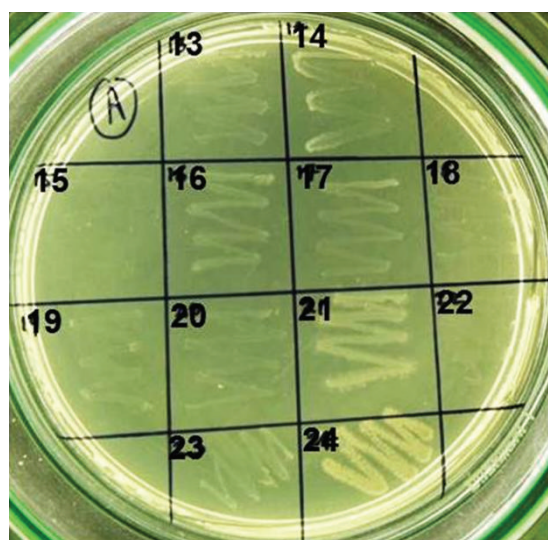

(b1)

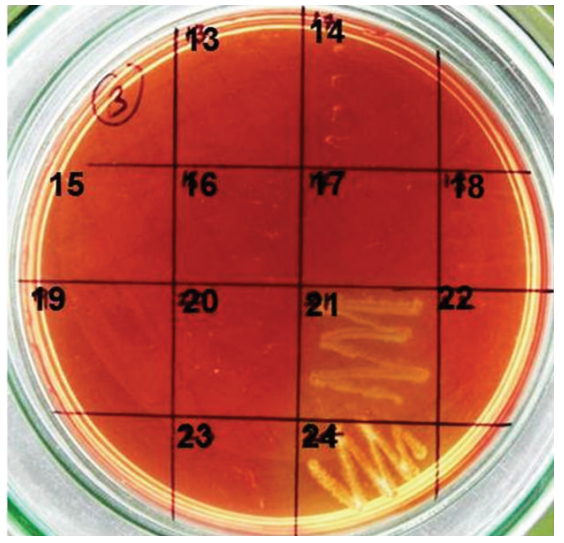

(b2)

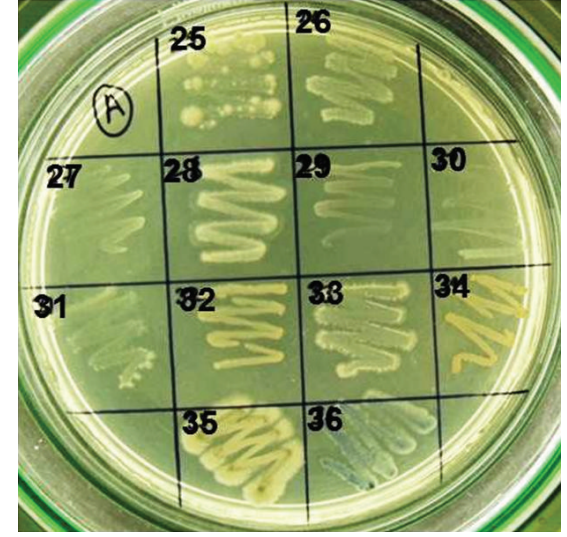

(c1)

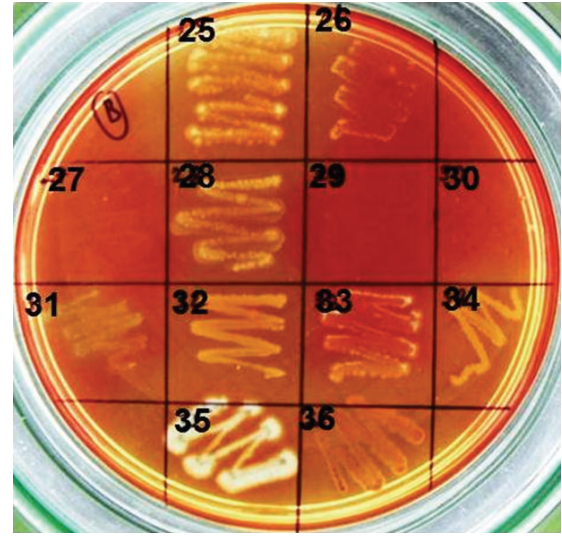

(c2)

Figure 1: Petri plates containing $1 \% \mathrm{CMC}$ agar incubated at $37^{\circ} \mathrm{C}$ for $96 \mathrm{~h}$. (al), (b1), and (c1) colonies before staining with $0.3 \%$ congo red; (a2), (b2), and (c2) colonies after staining.

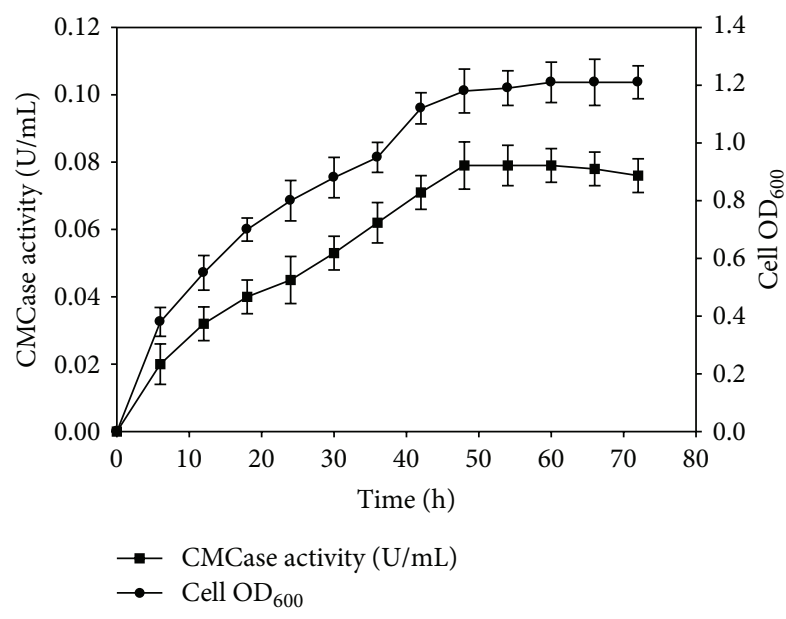

FIGURE 2: Enzyme production profile and growth curve of strain SS35.

protein-coding genes such as RNA polymerase (rpoB) gene [40], RNA polymerase sigma factor $(r p o \mathrm{D})$ gene, Gyrase B (gyrB) gene [41], and gyrase A (gyrA) gene [28] can be used for the identification of closely related taxa, because the

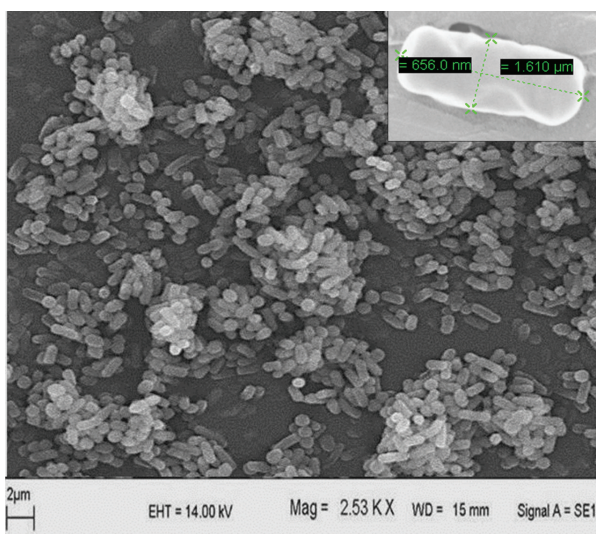

FIGURE 3: SEM micrograph for morphological characterization of isolate SS35 (inset: enlarged micrograph of a single cell).

genetic variation in protein-coding genes are much higher. Chun and Bae [28] demonstrated that the gyrA sequences, code for DNA gyrase subunit A, can be used for accurate identification of Bacillus amyloliquefaciens and related taxa including Bacillus subtilis, Bacillus vallismortis, Bacillus mojavensis, Bacillus atrophaeus, and Bacillus licheniformis. 


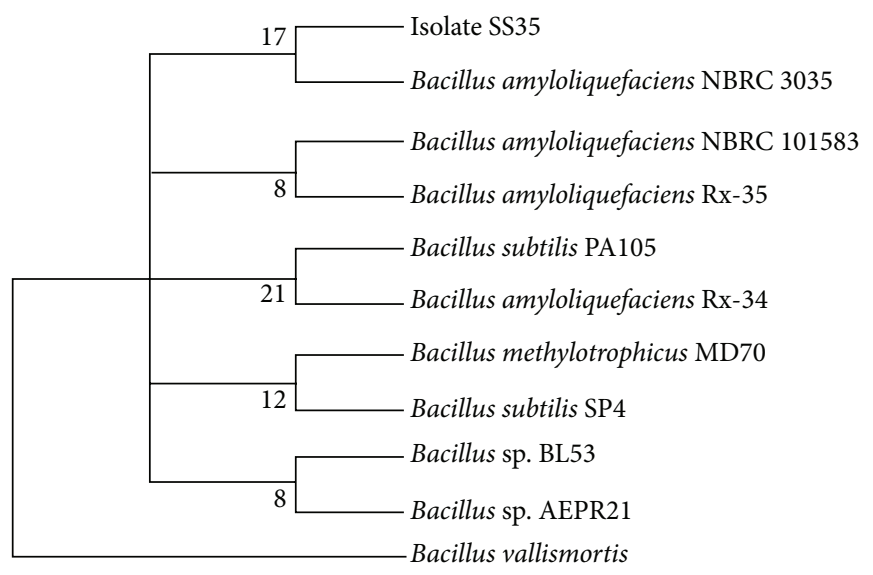

Figure 4: Neighbor-joining tree based on 16S rDNA sequences of Bacillus amyloliquefaciens SS35.

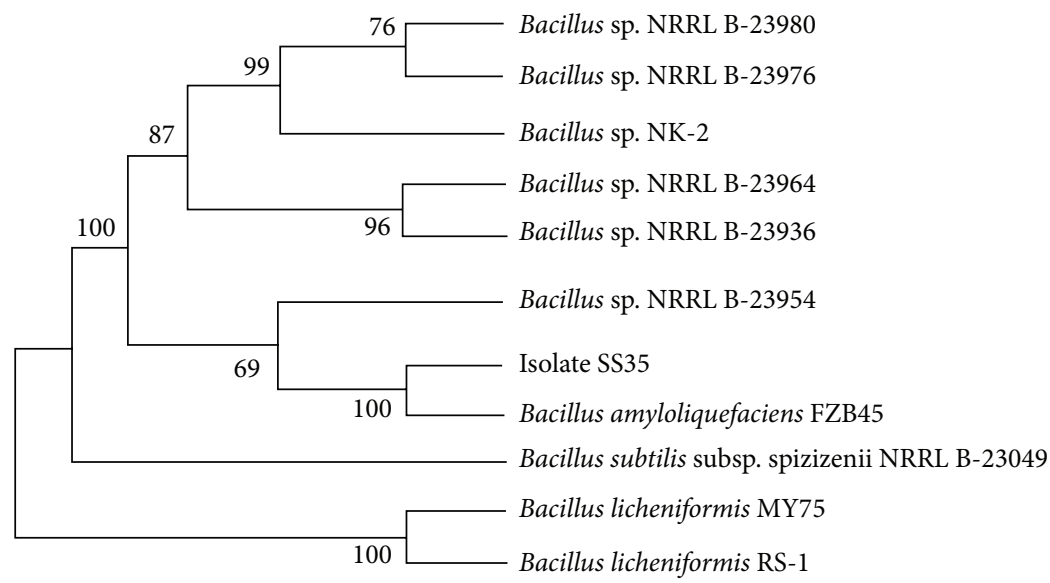

FIGURE 5: Neighbor-joining tree based on partial gyrA gene sequences of Bacillus amyloliquefaciens SS35.

Therefore, in this study partial gyrA gene sequences have been used for the confirmation of the result obtained from $16 \mathrm{~S}$ rDNA sequence analysis. The phylogenetic analysis using partial gyr A gene sequences also revealed that the isolate SS35 has the highest homology with Bacillus amyloliquefaciens FZB45 (GenBank accession no.: FN662840.1) [42], as shown in Figure 5. Numbers at nodes of the tree are indications of the levels of bootstrap support based on a neighbor-joining analysis of 1,500 resampled datasets. The isolate SS35 was identified as Bacillus amyloliquefaciens and designated as Bacillus amyloliquefaciens SS35. The 16S rDNA and gyrA gene sequences of the isolate B. amyloliquefaciens SS35 have been deposited in the NCBI nucleotide sequence database under the accession nos. JX674030 and KF019284, respectively.

\section{Conclusions}

Cellulose hydrolytic bacteria have been isolated from rhinoceros dung, and some potent cellulose degrading bacteria have been identified. Among all cellulolytic bacteria, isolate no. 35 exhibited maximum CMCase production and has been further characterized by biochemical methods. Bacterium has been identified as Bacillus amyloliquefaciens SS35 on the basis
TABle 2: Differential characteristics of Bacillus amyloliquefaciens SS35.

\begin{tabular}{lc}
\hline Characteristic/biochemical test & Observation \\
\hline Cell shape & Rod \\
Cell size & $0.5-0.6 \mu \mathrm{m} \times 1.5-1.6 \mu \mathrm{m}$, \\
Gram's reaction & + \\
Endospore formation & + \\
Acid production from & \\
$\quad$ Glucose & + \\
Lactose & + \\
Sucrose & + \\
Catalase test & + \\
Urease test & - \\
NO & reduction into $\mathrm{NO}_{2}$ \\
$\mathrm{H}_{2} \mathrm{~S}$ production & + \\
Starch hydrolysis & - \\
Growth between 20 and $50^{\circ} \mathrm{C}$ & + \\
\hline
\end{tabular}

+: positive reaction; -: negative reaction.

of 16S rDNA and partial gyrase A gene sequence analyses. The CMCase production has been observed to be associated 
with cell growth and has maxima at the late exponential phase of growth. Optimization of medium composition and fermentation parameters can further increase the cellulase production from $B$. amyloliquefaciens SS35. These attributes also make B. amyloliquefaciens SS35 a potential candidate in solid state fermentation for CMCase production using cellulosic biomass.

\section{Acknowledgment}

Research funding from Department of Biotechnology, Government of India, for this work is gratefully acknowledged.

\section{References}

[1] Y. Sun and J. Cheng, "Hydrolysis of lignocellulosic materials for ethanol production: a review," Bioresource Technology, vol. 83, no. 1, pp. 1-11, 2002.

[2] C. Martín, Y. López, Y. Plasencia, and E. Hernández, "Characterisation of agricultural and agro-industrial residues as raw materials for ethanol production," Chemical and Biochemical Engineering Quarterly, vol. 20, no. 4, pp. 443-447, 2006.

[3] O. J. Sanchez and C. A. Cardona, "Trends in biotechnological production of fuel ethanol from different feedstocks," Bioresource Technology, vol. 99, no. 13, pp. 5270-5295, 2008.

[4] E. A. Bayer, R. Lamed, and M. E. Himmel, "The potential of cellulases and cellulosomes for cellulosic waste management," Current Opinion in Biotechnology, vol. 18, no. 3, pp. 237-245, 2007.

[5] M. K. Bhat and S. Bhat, "Cellulose degrading enzymes and their potential industrial application," Biotechnology Advances, vol. 15, no. 3-4, pp. 583-620, 1997.

[6] K. Murashima, T. Nishimura, Y. Nakamura et al., "Purification and characterization of new endo-1,4- $\beta$-D-glucanases from Rhizopus oryzae," Enzyme and Microbial Technology, vol. 30, no. 3, pp. 319-326, 2002.

[7] K. Saito, Y. Kawamura, and Y. Oda, "Role of the pectinolytic enzyme in the lactic acid fermentation of potato pulp by Rhizopus oryzae," Journal of Industrial Microbiology and Biotechnology, vol. 30, no. 7, pp. 440-444, 2003.

[8] L. M. Roboson and G. H. Chambliss, "Celluases of bacterial origin," Enzyme and Microbial Technology, vol. 11, no. 10, pp. 626-644, 1989.

[9] Y. J. Lee, B. K. Kim, B. H. Lee et al., "Purification and characterization of cellulase produced by Bacillus amyoliquefaciens DL3 utilizing rice hull," Bioresource Technology, vol. 99, no. 2, pp. 378-386, 2008.

[10] B. K. Kim, B. H. Lee, Y. J. Lee, I. H. Jin, C. H. Chung, and J. W. Lee, "Purification and characterization of carboxymethylcellulase isolated from a marine bacterium, Bacillus subtilis subsp. subtilis A-53," Enzyme and Microbial Technology, vol. 44, no. 67, pp. 411-416, 2009.

[11] L. R. Lynd, P. J. Weimer, W. H. Van Zyl, and I. S. Pretorius, "Microbial cellulose utilization: Fundamentals and biotechnology," Microbiology and Molecular Biology Reviews, vol. 66, no. 3, pp. 506-577, 2002.

[12] M. Maki, K. T. Leung, and W. Qin, "The prospects of cellulaseproducing bacteria for the bioconversion of lignocellulosic biomass," International Journal of Biological Sciences, vol. 5, no. 5, pp. 500-516, 2009.
[13] N. Akhtar, A. Sharma, D. Deka, M. Jawed, D. Goyal, and A. Goyal, "Characterization of cellulase producing Bacillus sp. for effective degradation of leaf litter biomass," Environmental Progress and Sustainable Energy, 2012.

[14] A. Wahyudi, M. N. Cahyanto, M. Soejono, and Z. Bachruddin, "Potency of lignocellulose degrading bacteria isolated from Buffalo and horse gastrointestinal tract and elephant dung for feed fiber degradation," Journal of the Indonesian Tropical Animal and Agriculture, vol. 35, no. 1, pp. 34-41, 2010.

[15] R. H. Doi, "Cellulases of mesophilic microorganisms: cellulosome and noncellulosome producers," Annals of the New York Academy of Sciences, vol. 1125, pp. 267-279, 2008.

[16] G. A. Varga and E. S. Kovler, "Microbial and animal limitation to fiber digestion and utilization," Journal of Nutrition, vol. 127, no. 5, pp. 819-823, 1997.

[17] D. O. Krause, S. E. Denman, R. I. Mackie et al., "Opportunities to improve fiber degradation in the rumen: microbiology, ecology, and genomics," FEMS Microbiology Reviews, vol. 27, no. 5, pp. 663-693, 2003.

[18] D. L. Bushnell and H. F. Haas, "The utilization of certain hydrocarbons by microorganisms," Kansas Agricultural Experiment Station, vol. 199, pp. 653-673, 1941.

[19] Y. C. Lo, G. D. Saratale, W. M. Chen, M. D. Bai, and J. S. Chang, "Isolation of cellulose-hydrolytic bacteria and applications of the cellulolytic enzymes for cellulosic biohydrogen production," Enzyme and Microbial Technology, vol. 44, no. 6-7, pp. 417-425, 2009.

[20] R. M. Atlas, Handbook of Microbiological Media, CRC Press, Boca Raton, Fla, USA, 3rd edition, 2004.

[21] H. J. Ruijssenaars and S. Hartmans, "Plate screening methods for the detection of polysaccharase-producing microorganisms," Applied Microbiology and Biotechnology, vol. 55, no. 2, pp. 143-149, 2001.

[22] R. M. Teather and P. J. Wood, "Use of Congo red-polysaccharide interactions in enumeration and characterization of cellulolytic bacteria from the bovine rumen," Applied and Environmental Microbiology, vol. 43, no. 4, pp. 777-780, 1982.

[23] N. Nelson, "A photometric adaptation of the Somogyi method for the determination of glucose," Journal of Biological Chemistry, vol. 153, pp. 375-380, 1944.

[24] M. Somogyi, "A new reagent for the determination of sugars," Journal of Biological Chemistry, vol. 160, pp. 61-68, 1945.

[25] D. R. Boone, G. M. Garrity, R. W. Castenholz, D. J. Brenner, N. R. Krieg, and J. T. Staley, "Genus Bacillus," in Bergey's Manual of Systematic Bacteriology: The Firmicutes, vol. 3, pp. 21-128, Springer, New York, NY, USA, 2nd edition, 2001.

[26] J. C. Cappuccino and N. Sherman, Microbiology - A Laboratory Manual, Pearson Education Publication, New Delhi, India, 7th edition, 2004.

[27] N. Kannan, Laboratory Manual in General Microbiology, Panima Publishing Incarporation, New Delhi, India, 2002.

[28] J. Chun and K. S. Bae, "Phylogenetic analysis of Bacillus subtilis and related taxa based on partial gyrA gene sequences," Antonie van Leeuwenhoek, vol. 78, no. 2, pp. 123-127, 2000.

[29] J. D. Thompson, D. G. Higgins, and T. J. Gibson, "CLUSTAL $\mathrm{W}$ : improving the sensitivity of progressive multiple sequence alignment through sequence weighting, position-specific gap penalties and weight matrix choice," Nucleic Acids Research, vol. 22, no. 22, pp. 4673-4680, 1994.

[30] N. Saitou and M. Nei, "The neighbor-joining method: a new method for reconstructing phylogenetic trees," Molecular biology and evolution, vol. 4, no. 4, pp. 406-425, 1987. 
[31] M. Kimura, "A simple method for estimating evolutionary rates of base substitutions through comparative studies of nucleotide sequences," Journal of Molecular Evolution, vol. 16, no. 2, pp. 111$120,1980$.

[32] K. Tamura, J. Dudley, M. Nei, and S. Kumar, "MEGA4: Molecular Evolutionary Genetics Analysis (MEGA) software version 4.0," Molecular Biology and Evolution, vol. 24, no. 8, pp. 15961599, 2007.

[33] G. Immanuel, R. Dhanusha, P. Prema, and A. Palavesam, "Effect of different growth parameters on endoglucanase enzyme activity by bacteria isolated from coir retting effluents of estuarine environment," International Journal of Environmental Science and Technology, vol. 3, no. 1, pp. 25-34, 2006.

[34] Y. Liang, J. Yesuf, S. Schmitt, K. Bender, and J. Bozzola, "Study of cellulases from a newly isolated thermophilic and cellulolytic Brevibacillus sp. strain JXL," Journal of Industrial Microbiology and Biotechnology, vol. 36, no. 7, pp. 961-970, 2009.

[35] G. Rastogi, G. L. Muppidi, R. N. Gurram et al., "Isolation and characterization of cellulose-degrading bacteria from the deep subsurface of the Homestake gold mine, Lead, South Dakota, USA," Journal of Industrial Microbiology and Biotechnology, vol. 36, no. 4, pp. 585-598, 2009.

[36] S. K. Tai, H. P. P. Lin, J. Kuo, and J. K. Liu, "Isolation and characterization of a cellulolytic Geobacillus thermoleovorans T4 strain from sugar refinery wastewater," Extremophiles, vol. 8, no. 5, pp. 345-349, 2004.

[37] D. Deka, P. Bhargavi, A. Sharma, D. Goyal, M. Jawed, and A. Goyal, "Enhancement of cellulase activity from a new strain of Bacillus subtilis by medium optimisation and analysis with various cellulosic substrates," Enzyme Research, vol. 2011, Article ID 151656, 8 pages, 2011.

[38] H. Ariffin, N. Abdullah, M. S. U. Kalsom, Y. Shirai, and M. A. Hassan, "Production and characterization of cellulase by Bacillus pumilus EB3," International Journal of Engineering and Technology, vol. 3, pp. 47-53, 2006.

[39] G. E. Fox, J. D. Wisotzkey, and P. Jurtshuk, "How close is close: $16 \mathrm{~S}$ rRNA sequence identity may not be sufficient to guarantee species identity," International Journal of Systematic Bacteriology, vol. 42, no. 1, pp. 166-170, 1992.

[40] B. J. Kim, S. H. Lee, M. A. Lyu et al., "Identification of mycobacterial species by comparative sequence analysis of the RNA polymerase gene (rpoB)," Journal of Clinical Microbiology, vol. 37, no. 6, pp. 1714-1720, 1999.

[41] S. Yamamoto and S. Harayama, "Phylogenetic relationships of Pseudomonas putida strains deduced from the nucleotide sequences of gyrB, rpoD and 16S rRNA genes," International Journal of Systematic Bacteriology, vol. 48, no. 3, pp. 813-819, 1998.

[42] E. E. Idriss, O. Makarewicz, A. Farouk et al., "Extracellular phytase activity of Bacillus amyloliquefaciens FZB45 contributes to its plant-growth-promoting effect," Microbiology, vol. 148, no. 7, pp. 2097-2109, 2002. 

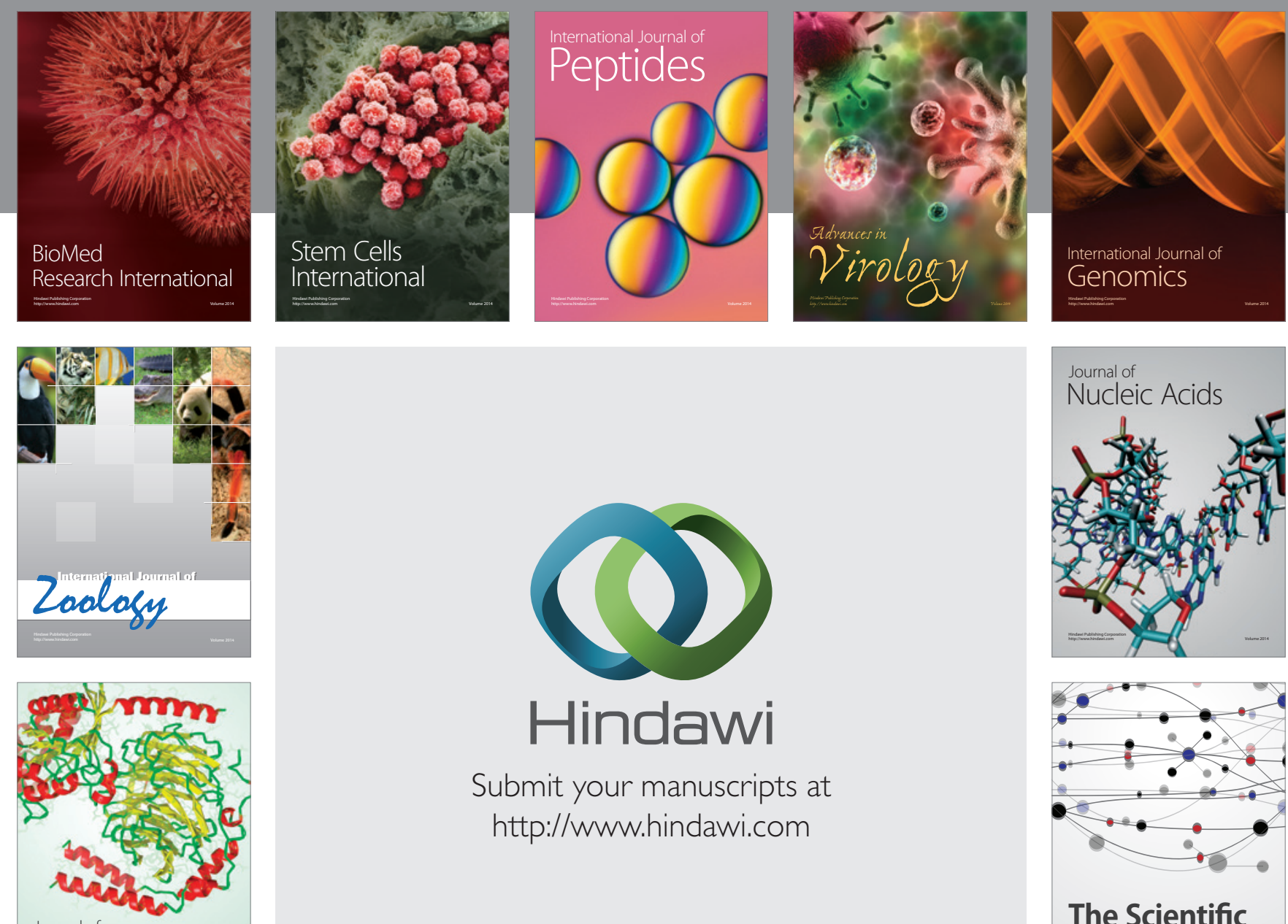

Submit your manuscripts at

http://www.hindawi.com

Journal of
Signal Transduction
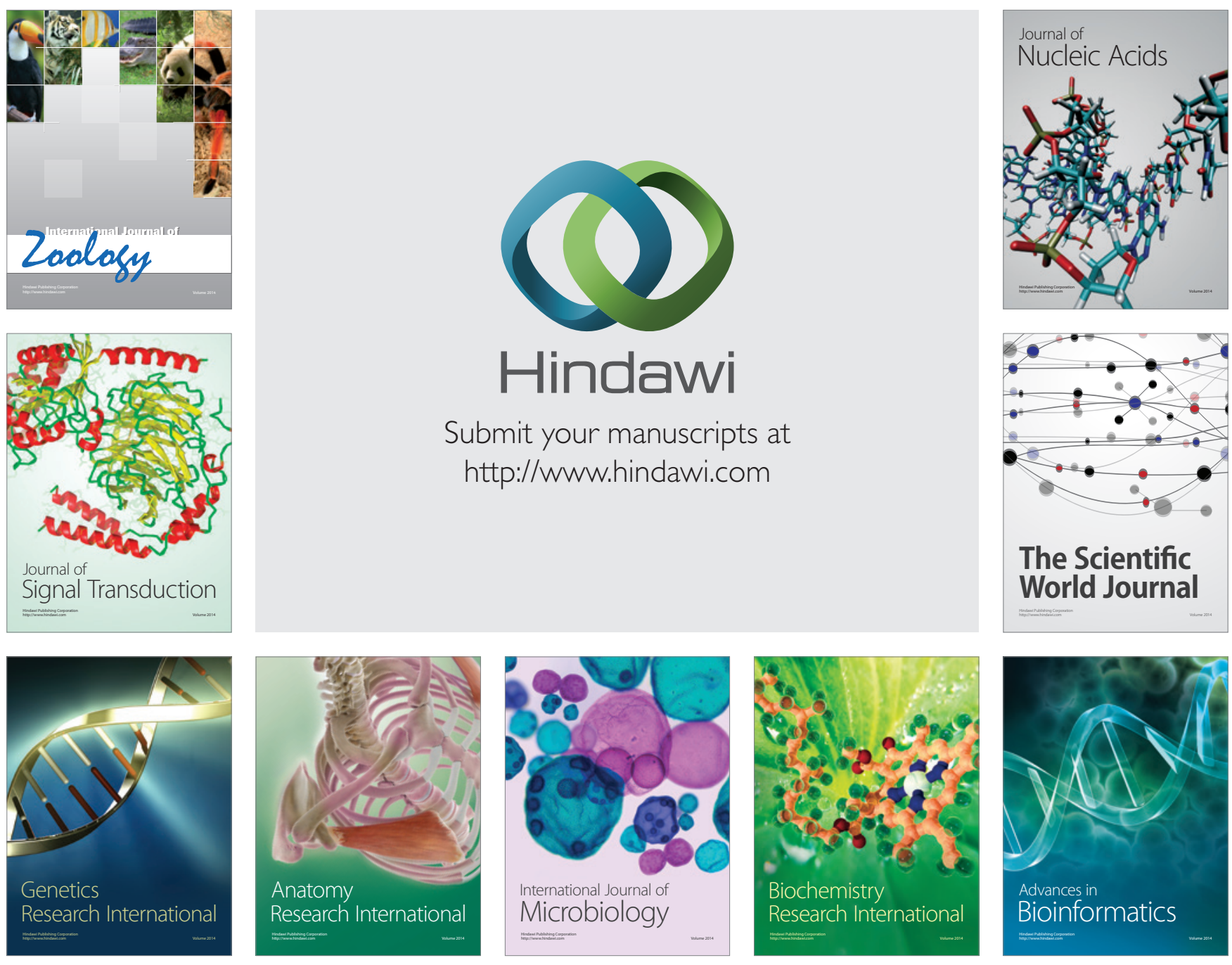

The Scientific World Journal
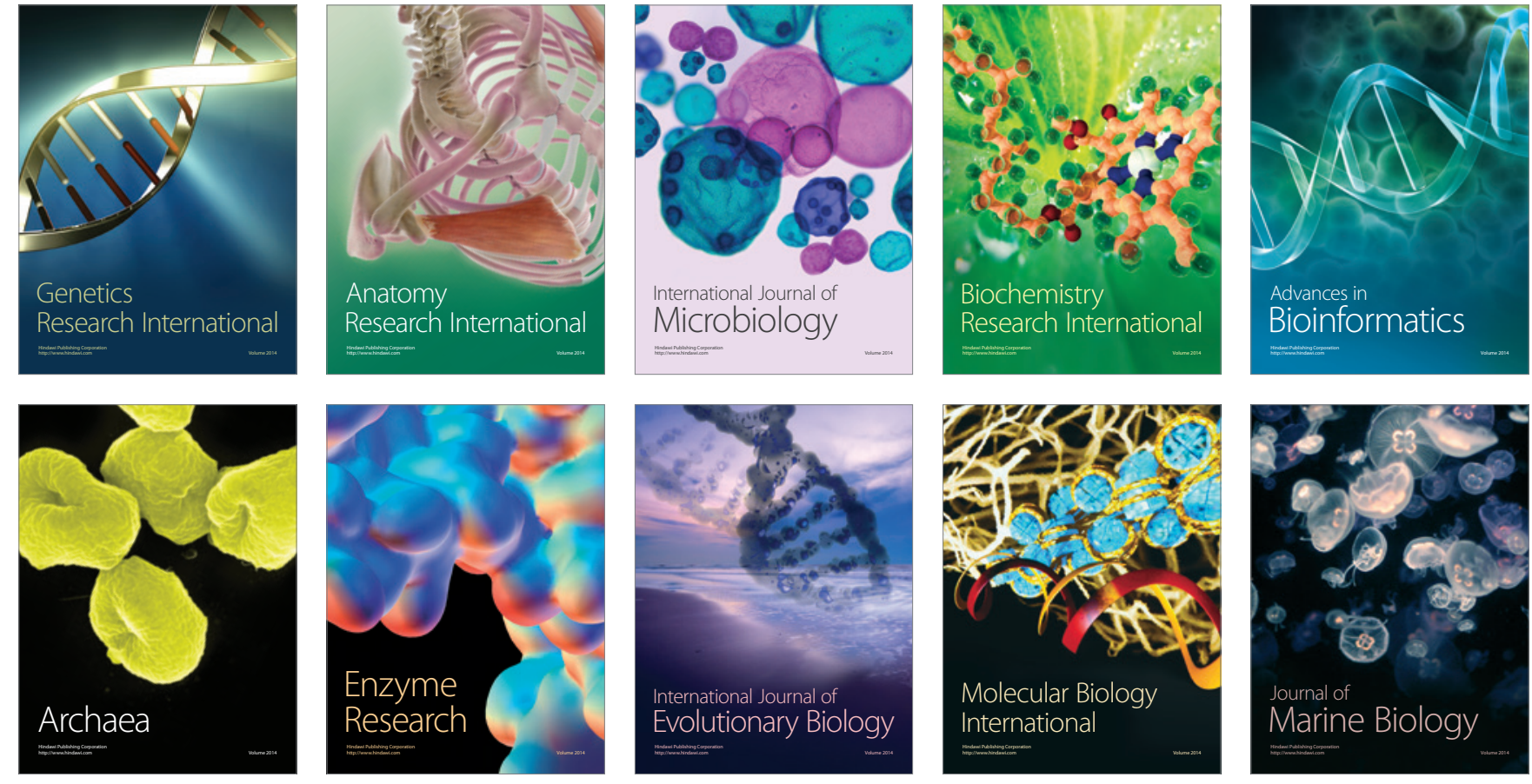